\title{
Scientific Freedom: Its Grounds and Their Limitations
}

Torsten Wilholt

Department of Philosophy, Bielefeld University, P.O. Box 100131, D-33501 Bielefeld,

Germany

twilholt@uni-bielefeld.de

Manuscript version.

The original article is forthcoming in Studies in History and Philosophy of Science and will be available at

http://www.sciencedirect.com/science/journal/00393681.

\section{Abstract}

In various debates about science, appeal is made to the freedom of scientific research. A rationale in favor of this freedom is rarely offered. In this paper, two major arguments are reconstructed that promise to lend support to a principle of scientific freedom. According to the epistemological argument, freedom of research is required in order to organize the collective cognitive effort we call science efficiently. According to the political argument, scientific knowledge needs to be generated in ways that are independent of the major political powers because of the important role it plays for the citizens and their capacity to form well-informed political preferences. Both arguments are examined critically in order to identify their strengths and limitations. I argue that the scientific freedom established by both rests on a number of critical preconditions, and that the arguments' force must be weighed against competing societal interests and values in each case of their application. Appeal to a principle of scientific freedom should therefore never mark the end, but rather the beginning of a public debate about the ends and means of science.

\section{Introduction}

Appeal to scientific freedom or the freedom of scientific research is commonplace in contemporary debates over research ethics and over science policy. Two recent examples may serve as illustrations. In March 2009, the World Congress for Freedom of Scientific Research convened at the European Parliament in Brussels. It was the second meeting of the congress and featured on its program, among others, the European Commissioner for Science and Research, members of several European governments, as well as a handful of Nobel laureates. The first meeting of the congress had been ini- 
tiated in response to restrictive legislation on stem cell research in Italy, and resulted in a declaration pronouncing the freedom of scientific research a "requirement for democracy, a civil and political right and one of the most important guarantees for man's health and well-being, as long as it does not provoke damages to others" (World Congress for Freedom of Scientific Research, 2008, p. 1).

The year before, on the other side of the Atlantic, the Union of Concerned Scientists published a statement entitled "Scientific Freedom and the Public Good", which was publicly endorsed by Steven Weinberg, Harold Varmus, Leon Lederman and many other scientists. The statement was formulated under the impression that the US administration under President George W. Bush had attempted to tamper with the findings of government research on issues like stem cells, climate change, sex education and contraceptives. In response, the UCS statement insists on government scientists' freedom "to conduct their work without political or private-sector interference", and calls on Congress and the executive branch to codify this freedom (Union of Concerned Scientists, 2008).

On that note, there are in fact countries that provide constitutional protection for the freedom of scientific research, including Germany, where this has been an element of constitutional tradition since the mid 19th century. In the present German constitution, the chapter on basic rights contains the stipulation that "Art and science (Wissenschaft), research and teaching are free". ${ }^{1}$

Despite its frequent and often emphatic endorsement, it is not always particularly clear what kind of liberties and protections a principle of freedom of research is intended to entail. Two very decisive ambiguities need to be noted at the outset. On the one hand, freedom of research can be understood just to imply that the scientists involved in research should themselves decide which projects and approaches to pursue. Call this the "freedom of ends". But over and above the freedom of ends, the principle of freedom of research is sometimes also appealed to in order to support the claim that society or the state must provide for the resources required to conduct all the research that the scientists deem important. This I shall call the "freedom of means" - recognizing, of course, that the associated claims need not always be quite as utopian as the expression suggests.

\footnotetext{
${ }^{1}$ Grundgesetz, Art. 5 (3). (The word "Wissenschaft" used in the original has a wider meaning than the English "science", comprising not only the natural and social sciences but also the humanities.) Similar clauses can be found in the constitutions of Austria, Greece, Italy, Portugal, Slovakia, Slovenia and Spain, as well as in the Charter of Fundamental Rights of the European Union, which became legally binding throughout most of the EU on 1 December 2009. Its 13th article reads: "The arts and scientific research shall be free of constraint. Academic freedom shall be respected."
} 
A second ambiguity concerns the question of who is the subject of the freedom. At first glance, this seems to be the individual scientist. But curiously, certain limitations of scientists' freedom, such as their dependence on research group leaders, or on supportive reviews by their peers for grant approval, are not commonly criticized under the rubric of freedom of research. Thus, it sometimes appears to be rather the right of a research community or even an entire discipline to determine its own research agenda by means of appropriate procedures of self-government which is the major concern behind appeals to scientific freedom.

What will concern me in this paper is the question why. Why should the human activity of scientific research enjoy any of these particular liberties? Today, the principle of freedom of research is almost always offered without explicit argument. One task of this paper will therefore be to reconstruct its grounds. Two major ways of arguing in favor of scientific freedom have been devised since at least the times of the Enlightenment, one of which one might call an epistemological argument, and the other a political one. They have both been historically important for establishing the idea of freedom of scientific research, but history will not be my main focus in this paper. My aim in reconstructing the arguments will be to probe their strengths and limitations in the contemporary context, in order to find out what kinds of liberties can reasonably be implied by the principle of freedom of research, and to assess what really is achieved by appealing to it in public debates about science.

\section{The epistemological argument}

What I will call the epistemological argument is a line of reasoning defined by its core premise, which can be formulated as follows: A principle of freedom of research creates optimal conditions for our collective search for knowledge. Variations of this premise have already been asserted by many of the early modern defenders of the freedom of philosophizing, including Campanella (1975), Descartes (1965, p. 3), Milton (1918, pp. 4350) and Spinoza (1925, p. 243). Obviously, in order to add up to a substantial argument, further qualifications and further premises are required (most notably, a specification of what 'our collective search for knowledge' is and the premise that, whatever it is, it is a good thing). But in trying to determine whether there is a version of the argument that can be systematically advocated today, I will start with this deliberately vague outline of the core premise.

John Stuart Mill (1991, chapter 2) is usually credited with the idea of justifying the core premise by means of an appeal to the fallibility of human judgment (cf. Feyerabend, 1981, pp. 65-71, Kitcher, 2001, pp. 94-96, Longino, 2002, pp. 3-4). Mill's is an argument for intellectual freedom broadly construed, on the grounds that an 
opinion may be true even if the consensus of the best minds deems it false. By suppressing an opinion, we might thus lose the opportunity to exchange an error for a truth. Even if the opinion is in fact false, its suppression still deprives humanity of the "livelier impression of truth, produced by its collision with error" (Mill, 1991, p. 21). But the argument from fallibility to the epistemic requirement of intellectual freedom is much older, as can be illustrated by the following passage from a speech by philosopher Nicolas Gundling, delivered at the University of Halle in 1711:

Step by step must the summit of truth be scaled, which rises between a thousand rocks and shrubs of opinions, such that it is virtually impossible for even the most diligent not to slip here and there and collide and grasp false things, before they reach the place where there is no more occasion for erring and slipping. But now imagine that the erring were not tolerated, the deceived were suppressed, and the ones who had stumbled were trampled and chased away. Who could still ascend to that highest pinnacle of truth? Therefore, freedom must be conceded to reason. (Gundling 1722, p. 823)

Gundling's speech, now all but forgotten, caused a stir in early 18th century Prussia, because it called for complete freedom of teaching and research for all four of the universities' faculties - a shocking conception at the time (cf. Paulsen 1896, pp. 530-531).

A contemporary version of the argument from fallibility, adapted to support the freedom of scientific research, might be conceived along the following lines. All prior judgments about the fruitfulness of research projects are fallible. It can not be precluded that projects which are at present not recommendable according to widespread standards will turn out to be groundbreaking. Therefore, scientists should choose their approaches and projects freely, such that a wide variety of approaches ends up being pursued. Some of these will prevail and lead to new knowledge, but it is impossible at any time to predict which ones these will be.

Two preconditions of this line of reasoning need to be inspected. One is the notion that freedom of choice on the part of the scientists will actually lead to a diversity of approaches; the other is the supposition that a diversity of approaches will actually improve our collective attainment of knowledge more than our collective attainment of error. I will start with the latter.

It is a venerable assumption that, under conditions of free inquiry, falsehoods will in the long run disappear while truths will prevail. I will call this the Milton asymmetry, after John Milton's dictum: "Let her and Falsehood grapple; who ever knew Truth put to the worse, in a free and open encounter?" (Milton, 1918, p. 59) The mechanism by which this is supposed to be brought about is already suggested in the 
Milton quote: it is the mechanism of mutual criticism. Here is how Christian Wolff describes it as early as 1728 :

One person acknowledges the truth taught by the other and uses it to detect further truth. Another one points out an error that has been made or improves upon it; and the one who has made it acknowledges it and tries to correct it, if it has not already been corrected by others. Thus is the growth of the sciences advanced by means of joined forces. (Wolff, 1996, p. 228)

The importance of mutual criticism has since been emphasized by many philosophers, perhaps most prominently by Mill (1991, chapter 2) and by Karl Popper (1972, pp. 3335, 260-261). More recently, David Hull (1988, pp. 305-321, 341-353) has pointed out the importance of scientists' need to build up on the work of others as an incentive for checking each others' results: The checking does not occur all the time, but it will happen every time a scientist suspects that the success of her own work is threatened by a possible mistake in another researcher's result.

It is appropriate to draw attention to the fact that the proper functioning of mutual criticism presupposes a certain degree of independence amongst researchers. For example, if an error is systematically rooted in false background assumptions or inadequate methods, then mutual checking is unlikely to reveal this error as long as everyone adheres to the same methods and background assumptions. The historical fact of scientific revolutions demonstrates that scientists can under certain conditions attain the required independence to overcome even deep-rooted mistaken presumptions, but it cannot dispel each and every doubt that the collective bias of the scientific community may still often make misconceptions undetectable even under conditions of open mutual criticism. Indeed, the proponent of the epistemological argument need not deny this. Her case rests on a relative epistemic advantage of diversity over uniformity. Ultimately, she only needs to claim that the chances of the sciences to display the Milton asymmetry in the long run are better given a diversity of approaches then they would be in a scientific monoculture. I will assume that the mechanism of mutual criticism justifies optimism that this is the case, as long as there is some independence among scientists.

The other problem, of explaining why a principle of freedom of research is a particularly good means of creating a diversity of approaches, may be the more difficult one. The researchers' desire for scientific credit can provide a starting point for an explanation. Scientific credit is awarded according to priority rule: usually, only the first researcher to come up with a result is credited with it. Therefore, the chances of success for an individual scientist not only depend on the intrinsic potential of her approach, but also on the number of other researchers who are pursuing the same ap- 
proach at the same time. If this number gets too high, she is likely to increase her individual prospect of credit by switching to a different, less overrun approach-even if the latter should have lower intrinsic potential. In the case of a co-operative group, it will often be possible for each individual within the group to improve her prospects for credit if the whole group switches together. That way, a free choice of projects and approaches will lead to the allotment of some proportion of the total research effort to projects that, from the point of view of scientific orthodoxy, have less than optimal prospect of success. ${ }^{2}$

It is however not sufficient to show that free choice of projects and approaches is likely to create some diversity. In order for the epistemological argument to succeed, freedom must be a better means of organizing cognitive diversity than other available ways. Could not the cognitive diversity in the sciences also be organized by one or more central authorities? What kind of advantages or disadvantages would that imply? Such a centralized endeavor would certainly require the processing of a great amount of knowledge, both global and local. Here, global knowledge means knowledge about seminal theories, about technological developments, about the past successes and failures of diverse methods, about the state of the art in each approach to each problem and about the amount of research effort currently expended on it. Local knowledge, in contrast, is information about the faculties, skills and specialized knowledge of individual researchers, about the combination of these qualifications in actual groups, about existing and possible cooperation and networks, as well as about the availability of equipment at every particular research institution. Global as well as local knowledge in this sense is perpetually in flux and requires constant updating for reasonable decision-making.

Centralized authorities would ideally have to possess complete and detailed global and local knowledge in order to distribute cognitive labor efficiently. While a great part of the required global knowledge can in principle be extracted from published sources, the required local knowledge, which is initially dispersed over the whole scientific community, is obviously deeply problematic in this respect. The need to unremittingly ascertain this massive amount of local knowledge, bring it into a communicable form, communicate it to centralized authorities and process it there puts every centralized scheme of organizing the cognitive division of labor at a tangible disadvantage.

2 This explanation is modeled on Philip Kitcher's description of the division of cognitive labor (1990, 1993, chapter 8). Kitcher's account is presented in a different argumentative context; the defense of a principle of freedom of research was not his intention. 
Of course, the mechanism by which diversity arises from free choice of research approaches also presupposes that decentralized decision-makers have a lot of local knowledge-not only about their own local conditions, but also about those of their competitors. In contrast to a centralized authority, however, they can be satisfied with aggregated knowledge about the rest of the community. For example, a certain research group might base a reasonable estimation of their varying chances for success within two different possible approaches on the information that their amount of access to accelerator radiation is below average (relative to their sub-discipline), but they as a group possess an above-average concentration of mathematical skills. This kind of knowledge can plausibly be assumed to be available to researchers by way of inductive generalization, as long as they regularly interact and communicate with a fairly representative proportion of their colleagues. It will typically be incomplete and less than optimally reliable, but not as incomplete and unreliable as what we would very probably get if we tried to gather up all the information required for producing the complete, detailed map of local knowledge that a centralized decision-maker would need.

This variety of the argument bears some similarity to Friedrich Hayek's (1945) epistemological case for liberalism. Critical as one can, and in my own opinion, should be of Hayek's often sweeping assumptions and his implausible optimism that the market will make everything turn out right, he did identify a decisive advantage which decentralized schemes of decision-making sometimes have-their good access to, in Hayek's words, "knowledge of the particular circumstances of time and place" (ibid., p. 521). Nevertheless, it is befitting to note that the argument at issue is only loosely analogous to Hayek's own line of reasoning; in particular, it is missing the distinctively economical element. The required aggregated local knowledge is not automatically conveyed to the decentralized agents by means of a price mechanism, but has to be communicated by means of open and regular interaction between the members of the community.

Considered together, all these lines of reasoning do suggest that freedom of research in a certain sense can in fact be an advantageous form of organization for a collective knowledge generating effort. But important qualifications have to be taken into account. So let us take stock.

\section{Qualifications and limitations regarding the epistemological ar- gument}

As a first qualification, we will have to address the question of which variety of freedom of research can be supported by the epistemological argument. The claim that a prin- 
ciple of freedom of research leads to epistemically advantageous cognitive diversity is based on the researchers' (or research groups') ability to make a choice that reflects their local knowledge and their individual prospects for credit. This means that the epistemological argument can only support a principle of individual freedom of research. The principle must entail that the choice should be made by the researchers or within the research groups that will actually perform the research. The argument can not be used to justify the principle that research decisions should be made somewhere within the discipline, or somewhere within the scientific community, because this claim cannot invoke the same epistemic advantages which make all the difference for the epistemological argument. The question of whether the epistemic argument can support only freedom of ends or also freedom of means depends crucially on the evaluation of the epistemic ends of the scientific enterprise. As a requisite for succeeding to motivate even a mere freedom of ends, the knowledge aimed at by scientific research must promise to be at least potentially of some positive value to the political collective as a whole. The degree to which, in addition, freedom of ends is granted to any epistemic enterprise depends on the relative value of the knowledge aimed at as compared to the expected outcomes of other political measures or collective enterprises that compete over the resources of the community. It is beyond the scope of this paper to attempt an assessment of this value for any particular scientific research program. ${ }^{3}$ For our present purposes, it is worthwhile noting that the value of a piece of scientific knowledge, and thus the extent and exact type of scientific freedom defensible on epistemological grounds, is likely to vary among scientific disciplines and even among scientific research programs.

A second qualification is that the argument as presented presupposes an adequate system of incentives for researchers, motivating them to try and come up first with solutions to scientific problems. Though the scientific credit system is in many cases up to the task, in some cases it may not be. In big science, for example, a single experiment can take the continuous effort of dozens of researchers over a time span of many years, with little opportunity for the participants to continuously earn credit along the way. Without centralized intervention, the credit system itself might not provide sufficient incentives to partake in this kind of research.

A third and last qualification that I would like to call attention to is the following precondition: All researchers need constant updating of their global and, at least in aggregated form, also their local knowledge about the rest of the community. The principle of freedom of research, insofar as it can be supported by the epistemological argument, is thus inseparable from a principle of free and open interaction and com-

${ }^{3}$ For a convincing analysis of the issues that would be involved, see Bergström (1994). 
munication within the sciences. Without this, the promised epistemic benefits of individualized freedom of research can not be expected to unfold.

In sum, the epistemological argument can plausibly show that under certain conditions - notably free communication and a functioning system of incentives - individualized freedom of research will lead to a diversity of scientific approaches that can be expected to surpass the epistemic yield of centralized forms of research organization. While this result is interesting enough to bar the dismissal of freedom of research as pure rhetoric or scientific ideology, ${ }^{4}$ it also clearly falls short of what many defenders of the freedom of science had and have in mind.

\section{The political argument}

As noted above, there is a second line of reasoning which could be used to argue in favor of freedom of research and which is largely independent of the epistemological argument. It is in essence a political argument and arises from the consideration that scientific knowledge has become an important input for the democratic process. In making their political choices, citizens are in many ways relying on their beliefs about what the world is like, and ever so often they turn to science in order to resolve uncertainties. On the basis of this observation, it can be argued that the practices and institutions generating the scientific knowledge that citizens rely upon should enjoy independence from the major political powers. Otherwise, the democratic process would be undermined, in a similar fashion as it would be if the press, for example, was subject to the control of the government.

The political argument, too, has a long history. One of its earliest explicit uses was in Condorcet's report to the French Legislative National Assembly, submitted in 1792. He had been commissioned to propose ideas for the re-organization of science and education in post-revolutionary France. The following maxim is presented as one of the guiding principles of his sketch:

Finally, no public power must have the authority, not even the standing, to prevent the development of new truths or the teaching of such theories that contradict its particular politics or its present interests. (Caritat 1968, p. 453)

He explains that the continuous progress of the republic calls for unremitting criticism, and that a public authority interfering with academic matters would thereby "contradict the purpose of the whole social institution: the perfecting of the laws." (Ibid., p. 523) Variations of this argument were also used in the $19^{\text {th }}$ century by democ-

${ }^{4}$ Some writers have been tempted to simply dismiss the notion in this way; see Hollinger (1990) and Sarewitz (1996), p. 10. 
ratic theorists in the German countries at the time when scientific freedom was first formulated as a constitutional principle. As one of them summarized:

The combination of these two principles, the rule of majorities in the realm of ends, and the rule of freedom and anarchy in the realm of theory, constitutes the only correct method of political life and progress. (Fröbel 1850, p. 107)

There can be little doubt that the political argument has been of crucial importance for the historical development of scientific freedom as a political principle. ${ }^{5}$ However, the more important question for our present purposes is whether it can be reconstructed as a convincing argument in the context of today's democratic societies.

The core of the political argument seems to consist simply in the claim that politically independent scientific research is such an important resource for democratic self-government that it deserves special protection. Put in this way, an apparent problem arises, suggesting that matters cannot be quite that straightforward. A special protection of science by means of a principle of freedom or autonomy is also a limitation of the citizens' power to govern themselves, because it would, if it is at all effectual, have to limit the power of the citizens for example to put a stop to some line of scientific research-even if the majority did not approve of it. Political philosophers have discussed the same kind of problem with respect to the principle of freedom of speech, which, according to Ronald Dworkin (1985, pp. 62, 391), at the same time strengthens and weakens democracy and curtails the power of the citizens as a whole, for analogous reasons.

This impression, however, depends on the idea that the relevant power of the citizens is adequately characterized as "the power to make it more likely that political decisions will be made as one wishes", as Dworkin explicitly presupposes (ibid., p. 62). This may be too restricted a view of the democratic process, because over and above the citizens' capability of making their preferences count, another important dimension of their power is their ability to develop political preferences in the first place that adequately reflect their actual interests and values. If this dimension of their power is taken into account, it is no longer obvious that principles of free expression and free inquiry entail curtailments of the power of the citizens as a whole. This way

\footnotetext{
${ }^{5}$ This is powerfully illustrated by the fact that it was the moderate liberal Friedrich Dahlmann who, in 1848 , first suggested placing the freedom of science under constitutional protection in Germany (to a committee convened by the German Confederation to devise a new constitution, cf. Hübner, 1967, p. 76). Dahlmann himself had earlier given a defense of scientific freedom along the lines of the political argument; see Dahlmann (1886). His suggestion made it into the draft constitution of the Paulskirchenversammlung, which itself never went into effect, but which served as a blueprint for later democratic constitutions in Germany.
} 
of addressing the problem suggests that the formation of political preferences on the basis of the exchange of information and arguments should be considered part and parcel of the democratic process, as has long been argued by proponents of deliberative conceptions of democracy (in particular, see Cohen 1989). A view that takes preferences as given and treats the democratic process as merely a means to their aggregation, in the words of Cass Sunstein, "fails to do what democracy should - that is, to offer a system in which reasons are exchanged and evaluated. A well-functioning system of democracy rests not on preferences but on reasons." (1997, p. 94)

Based on these qualifications, the political argument for freedom of scientific research can be articulated more precisely. The right point of departure is the observation that the crucial import of the democratic process is to lead to policies and decisions that reflect the citizen's well-informed political preferences. Only thus can democratic politics be said to be based on the citizens' actual needs, interests and values. It is this characteristic that confers the kind of legitimacy on democratically constituted political power that other, non-democratic kinds of political procedures cannot bestow. ${ }^{6}$ But this legitimacy must end where executive or legislative action would threaten to undermine just those characteristics of the democratic process that are essential for its legitimacy-conferring nature. These essential conditions include, among others, the citizens' ability to gain the knowledge they require to develop well-informed preferences. And they include free scientific research insofar as scientific knowledge is required for informed choices within today's democracies. A principle of freedom of research established on the basis of this argument thus limits democratically legitimized power only at the point where its exertion would threaten to undermine its own legitimacy.

Note that the political argument, thus conceived, is not just a variety of the epistemological one. Its aim is not to guarantee that the knowledge needed by the citizens is generated in as efficient a way as possible. Its punch line is rather that it must be generated in ways that are independent from the major political powers, because no political power can have legitimate control over the generation and distribution of the same knowledge that serves as an input to the democratic process without thereby undermining whatever democratic legitimacy might otherwise justify its control over science. $^{7}$

The idea that democratic power would be self-undermining if it extended so far as to include also power over the sources of those pieces of knowledge that feed into

${ }^{6}$ Cf. Joshua Cohen's (1996) articulation of the "ideal of democratic justification".

${ }^{7}$ For a comparable analysis of a "right to inquiry" as a distinctively political conception see Brown and Guston (2009). 
the democratic process is already present in the above quotes by Condorcet and in the thoughts of other Enlightenment thinkers. But science and society have changed since the time of the Enlightenment, and so the argument must be subjected to further scrutiny.

\section{Qualifications and limitations regarding the political argument}

One distinguishing feature of Enlightenment arguments for free inquiry is that they presuppose the subjects of this freedom to be participants in a public intellectual discourse-as perhaps most characteristically expressed in Immanuel Kant's emblematic assertion that the "freedom in question" was the "freedom to make public use of one's reason in all matters" (Kant, 1991, p. 55). It has been argued to be doubtful whether scientists can still lay claim to this kind of role in contemporary societies and suggested that therefore the political argument does not carry over well to present conditions of science (cf. Böhme, 2006).

There is one aspect in which this criticism must be acknowledged to point out a limitation. The political argument does clearly not apply to research endeavors whose results never reach the participants of public political discourse. Thus, it cannot be appealed to in contexts where the accessibility of research results is going to be restricted, be it for reasons of national security or on account of a sponsor's commercial interests. Beyond this important caveat, however, there is little reason to restrict the import of the political argument to scientists qua public communicators. If governmental control over the public communication of research results would undermine the democratic process, then so would control over the research process generating these results. As long as research results keep finding their way into the public sphere, the fact that most scientists do not routinely participate in public discourse does not diminish the significance of the political argument.

However, perhaps it is rather our trust in the political innocence of science that has diminished so much since the times of the Enlightenment that it undercuts confidence in the political argument. As John Dewey wrote on the verge of World War II: "It is no longer possible to hold the simple faith of the Enlightenment that assured advance of science will produce free institutions." (1988, p. 156) Of course, the above reconstruction of the political argument does not require us to adopt this simple faith. It rests on the much weaker claim that politically independent scientific research is one of the epistemic preconditions of a well functioning democratic political order in our time.

Still, this might be regarded as presupposing the political innocence of science in a certain sense. After all, the political argument builds on the assumption that the re- 
sults of scientific research will help citizens to develop well-informed political preferences. It might seem that this presupposes the ability of science to provide information that is politically impartial, i.e. untainted by any political preferences that those involved in its generation and dissemination may already hold. But this view of the political neutrality of science has been persistently criticized, in particular by those engaging in social studies of science. ${ }^{8}$ Recent political controversies in which scientific input has played an important role, such as the disputes over genetically modified crops or the various debates related to climate change, have sometimes left analysts with the impression that science, instead of functioning as an impartial arbiter, more typically offers a breadth of positions on the respective matter, more or less reflecting the spectrum of political opinions in the wider population (cf. Sarewitz 2004). There is a plausible explanation of why the real world phenomena at issue in political controversies often lack a uniform scientific assessment. These phenomena have found their way onto the research agenda not because they conveniently lend themselves to treatment in line with the well-tried methodology of an established laboratory practice, but in virtue of their social, economic and political significance. Their inherent complexity allows and demands a variety of methodological approaches. As Daniel Sarewitz concludes, "science, in doing its job well, presents this richness, through a proliferation of facts assembled via a variety of disciplinary lenses, in ways that can legitimately support [...] a range of competing, value-based political positions." (Ibid., p. 386)

But do these observations and insights diminish the persuasiveness of the political argument for the freedom of research? The question is not whether the presence of scientific practices and institutions that are not under the control of the major political powers puts citizens in an epistemic position that is perfectly adequate to the task of developing well-informed political preferences. It is rather whether this position is an essential improvement over an epistemic situation where there is no scientific research, or only such research as is conducted under the control of political powers. The situation of being confronted with conflicting voices of scientific expertise concerning the extent and likely consequences of global warming for example may be less then perfect, but it presents an epistemic advantage over the situation of never having heard of global warming, which would almost certainly be our condition if there had been no scientific research into the matter. Even if there was some scientific research, but it was conducted under the control of political powers, the probability would be high that out of the wide variety of methodological approaches permitted by the complex real world problem of climate change, those lines of research whose results happened to coincide with the particular interests of the controlling political powers would have a

${ }^{8}$ For synopsis, see Bimber and Guston (1995) and Jasanoff and Wynne (1998). 
markedly increased likelihood of being pursued and publicized. Arguably, this would most probably decrease the degree to which the totality of accessible research results adequately represents the actual threats and possibilities inherent in the situation that we find ourselves in. Having access to an adequate representation of those actual threats and possibilities, and be it in the form of a whole range of partly conflicting predictions, is an important starting point for the development of preferences that reflect our interests and values. Therefore, political independence of scientific research in an organizational sense can carry decisive epistemic advantages for the citizens, despite the lack of political neutrality in typical real world cases of politically relevant research that many have observed.

However, this advantage rests on an important precondition. I have argued that the variety of approaches pursued by politically independent scientists would indeed provide scientific results that, as a whole, constitute a more adequate representation than a more selective kind of research such as one would expect under conditions of political control. But this means, again, to assume that the scientific enterprise, if uncontrolled by the political powers, will in fact produce a pluralism of approaches. Under the conditions of such pluralism, individual biases may balance each other and also provoke productive scientific debate (cf. Solomon 2001, esp. chapter 8). Without pluralism, there would be no reason to assume that the one-sided approach that the scientific community would settle on would put citizens into a better epistemic position than the one-sided approach that might be favored by a government. As Helen Longino (1990, chapter 4) has argued, the degree to which scientific communities permit and encourage pluralism depends on the degree to which certain preconditions are realized in their social organization, such as equality of intellectual authority, existence of recognized forums for criticism, and commitment to taking up criticism. For our present discussion, I wish to emphasize only the following: The persuasiveness of the political argument for freedom of research depends critically on the assumption that research communities are organized in such a way as to encourage exploitation of the full range of varied approaches that real world problems permit.

Another issue to address in assessing the strength and limitations of the political argument is the question of its scope. Clearly, not every branch of scientific research plays an equally important role in enabling the citizens to make well-informed political judgments. Can the political argument nonetheless be applied to argue for political independence for all of science, or is it restricted to those areas of research that possess at least some degree of political relevance?

Consider the following argument to the effect that the scope of the political defense of scientific liberty should not be thus restricted. It is modeled on similar argu- 
ments which have been made for the case of unrestricted freedom of speech (Meiklejohn, 1961, esp. p. 262) and begins with the observation that the boundary between what is politically relevant scientific research and what is not is diffuse and non-obvious. If the restriction of the kind of freedom established by the political argument to politically relevant research alone was to be practically feasible, someone would thus have to draw the dividing line that defines the area of political relevance in science. But who? Neither the research communities themselves nor the political powers are disinterested enough to be entrusted with this task. In fact, in the hands of the political powers, the power inherent in such a monopoly of definition would equal exactly that power which the political argument is designed to keep in check in the first place. How could any institution or societal process be trusted to establish the definition of political relevance without succumbing to the interests of political powers? The enormous practical difficulties inherent in this question pragmatically justify a presumption in favor of setting up the kind of scientific freedom which the political argument supports in as inclusive a way as possible, in order to prevent it from being eroded from its fringes under political pressure.

However, the political argument for free scientific research will inevitably be appealed to not only to claim a free choice of the ends of inquiry, but also to claim access to the required means for research in a way that is not under the immediate control of the government or other political parties. In fact, as far as the political argument is concerned, the freedom of ends becomes difficult to separate from the freedom of means. This is so because the generation of most scientific knowledge today requires great efforts and expensive equipment. If a politically independent science is important for the democratic process, this should therefore also be reason enough for democratic states to provide means for this enterprise which would otherwise simply not get off the ground. But admitting freedom of ends while leaving the means provided under the control of the government would evidently thwart also the freedom of ends for all practical purposes. Applied to the freedom of means, however, the above line of reasoning in favor of maximal scope for the political argument becomes feeble. In light of the limitation of resources, there is no such thing as a maximally inclusive right to the means for scientific research.

On a constructive note, it seems reasonable to suggest that access to the means of research, insofar as it is justified by a political argument in the present sense, should increase with the political relevance of the research project in question..$^{9}$ This sugges-

\footnotetext{
${ }^{9}$ Brown and Guston (2009) reach a similar conclusion on this point.
} 
tion cannot diffuse the worries about the definition of political relevance altogether. ${ }^{10}$ However, faced with the limitations of a world of finite resources, the societal challenge to determine the political relevance of scientific research in a way that avoids monopolies of definition becomes an inevitable one.

\section{Conclusions}

To wrap up the discussion of the political argument, I will briefly summarize its strengths and limitations. The argument rests on strong grounds, namely on the protection of an important precondition for the democratic process. Even so, it is worth noting that this is far from establishing an argument that trumps all other societal concerns. The principle supported by it stands in competition with other principles that can be defended as preconditions for the democratic process. This may be of particular importance in so far as access to the means for research is concerned. Note in this context that the preconditions for a functioning democratic process have been argued to include also the fulfillment of certain social needs, and thus to provide basic justification for welfare expenditures (Waldron 1993). Furthermore, there is a wide consensus that politically based principles such as these cannot trump basic individual rights.

One strength of the political argument is that it can reach beyond the level of the individual scientist. It is in principle also suitable for the defense of a whole research community or discipline's right to determine their own research agenda, undisturbed by the interference of political powers. Note, however, that this is due to the purely negative character of the argument. It is in essence an argument against political control of the research agenda that does nothing to establish a positive claim with regard to how the research agenda should be determined instead. While scientific self-government on the level of disciplines might be a convenient answer, it is not thereby established as the only feasible alternative. Besides the extreme options of control by major political powers on the one hand and pure disciplinary self-organization on the other, there might also be other ways to determine the scientific agenda by more inclusive and democratic procedures. For example, it is imaginable to employ some of the participative instruments that have been occasionally and tentatively employed in recent European science and technology governance, such as stakeholder hearings, citizen panels and consensus conferences (cf. Douglas, 2005, Hagendijk et al., 2005). The considerations of the political argument for scientific freedom, rightly understood, leave many options open.

\footnotetext{
${ }^{10}$ However, as political relevance now becomes a matter of degrees, it may alleviate them. Should the definition of political relevance be swayed by powerful political interference, the effect will at least be merely a gradual one.
} 
The strength of the political argument varies across different areas of research. We have seen that at least when conceived as an argument for the politically unregimented accessibility of means for research, the claims that can be established by it are proportional to the political relevance of the line of research in question.

As a genuine limitation of the political argument we discovered that it cannot hold sway for lines of scientific research whose results will be restricted in their accessibility. Another way to put this is to say that the argument is conditional on an effective system of communicating and publicizing research results. At least as importantly, we have seen that it is also conditional on a social structure of the research community that encourages a pluralism of approaches.

Compare this to the results of our earlier examination of the epistemological argument. It establishes an individualized free choice of research projects and approaches. One might call this a micro-autonomy, as the argument cannot be invoked to establish the autonomy of higher order actors such as disciplines or communities.

The function of the epistemological argument is to establish said micro-autonomy as an epistemically advantageous form of organization for collective knowledgegenerating efforts. The argument is therefore of decidedly instrumentalist character: its strength cannot surpass whichever value we attribute to the goal of attaining the kind of knowledge we expect to emerge from the research in question. In many cases, we have good reasons to assign great value to the epistemic aims of science-be it because they promise to enhance our understanding of our world and our place within it, or because they are expected to contribute to the development of technologies that will help solve our societal problems and improve our health and our prosperity. However, there are other individual and societal goals, and these are not incommensurable with our epistemic goals. Where freedom of research (as based on epistemic reasons) stands in conflict with other principles derived from other societal goals, the epistemic ends of research will have to be compared and weighed against these other goals, and the epistemological argument's strength will only be relative to the result of this weighing. The weighing also legitimately includes consideration of the cost of research-both in the narrower sense of financial cost and in the wider sense of risks and moral concerns. If a well-informed public deems any of these costs of a concrete line of research higher than the expected epistemic benefits, then these concerns can limit the claim to scientific freedom in that case.

As we have seen, the epistemological argument is conditional on a functioning system of incentives, or otherwise the claim that individual freedom will lead to an efficient division of cognitive labor cannot be compelling. We have also noted that the epistemological argument draws its persuasiveness from a claim to the efficient use of 
local and global knowledge about the research system, and that it is therefore conditional on a social structure of science that enables and encourages free and open interaction between scientists.

In comparison, one point worth noting is that both major arguments for scientific liberty bank on the advantages of pluralism and diversity in science. A simple way of extracting a moral from this is that pluralism and diversity in science will always be at least as valuable as scientific freedom - at least in so far as the latter is supported by the arguments I have reconstructed.

Comparison also makes clear that the two arguments partially overlap and in some sense also complement each other in terms of the kinds of scientific freedom they support. However, it is also obvious that neither of them is sweeping or absolute, that is to say that the force of each argument must be weighed against competing societal interests and values, and that there is no guarantee that together they cover the whole ground.

What is more, the force of each of these arguments is relative to weighings and calibrations that involve difficult value judgments, such as: What is the relative political significance of this line of research? How do the epistemic aims of this research project compare to, say, the goal of reducing the totality of human-inflicted suffering of higher animals? In a liberal democracy, none of these determinations can reasonably be left to the monopoly of any one agent or institution. They will consequently have to be subject to public deliberation. For this reason, appeal to a principle of freedom of research is not suitable to replace public deliberation on the ends and means of science. It should therefore never mark the end, but rather the beginning of public debate.

\section{References}

Bergström, L. (1994). Notes on the value of science. In D. Prawitz, B. Skyrms, \& D. Westerståhl (Eds.), Logic, methodology and philosophy of science IX (pp. 499-522). Amsterdam: Elsevier.

Bimber, B. \& Guston, D. H. (1995). Politics by the same means: Government and science in the United States. In S. Jasanoff et al. (Eds.), The handbook of science and technology studies (pp. 554-571). Thousand Oaks: Sage.

Böhme, G. (2006). Die Wissenschaftsfreiheit und ihre Grenzen. In M. Fischer \& H. Badura (Eds.), Politische Ethik II: Bildung und Zivilisation (pp. 19-28), Bern: Lang.

Brown, M. B. \& Guston, D. H. (2009). Science, democracy, and the right to research. Science and Engineering Ethics, 15, 351-366. 
Campanella, T (1975). The defense of Galileo (G. McColley, Trans., reprint). New York: Arno Press.

Caritat, M. J. A. N., Marquis de Condorcet (1968). Rapport et projet de décret sur l'organisation générale de l'instruction publique. In A. C. O'Connor \& M. F. Arago (Eds.), Oeuvres de Condorcet (reprint), vol. 7 (pp. 449-573). Stuttgart-Bad Cannstatt: Frommann.

Cohen, J. (1989). Deliberation and democratic legitimacy. In A. Hamlin, \& P. Pettit (Eds.), The good polity: Normative analysis of the state (pp. 17-34). Oxford: Blackwell.

Cohen, J. (1996). Procedure and substance in deliberative democracy. In S. Benhabib (Ed.), Democracy and difference: Contesting the boundaries of the political (pp. 95-119). Princeton: Princeton University Press.

Dahlmann, F. C. (1886). Die Zukunft unserer Universitäten. In F. C. Dahlmann's kleine Schriften und Reden (pp. 236-242). Stuttgart: Cotta.

Descartes, R. (1965). Epistola Renati Des Cartes ad celeberrimum virum D. Gisbertum Voetium. In C. Adam, \& P. Tannery (Eds.), Oeuvres de Descartes, vol. VIII-2 (pp. 1194). Paris: Vrin.

Dewey, J. (1988). Freedom and culture. In J. A. Boydston (Ed.), The later works, 19251953, vol. 13 (pp. 64-189). Carbondale: Southern Illinois University Press.

Douglas, H. (2005). Inserting the public into science. In S. Maasen, \& P. Weingart (Eds.), Democratization of expertise? Exploring novel forms of scientific advice in political decision-making (pp. 153-169). Berlin: Springer.

Dworkin, R. (1985). A matter of principle. Cambridge, Mass.: Harvard University Press.

Feyerabend, P. (1981). Problems of empiricism. Cambridge: Cambridge University Press.

Fröbel, J. (1850). System der socialen Politik, vol. 2. Leipzig: Verlagsbureau.

Gundling, N. (1722). De Libertate Fridericianae. In J. E. Kapp (Ed.), Clarrissimorum virorum orationes selectae (pp. 803-836). Leipzig: Martini.

Hagendijk, R., Healey, P., Horst, M., \& Irwin, A. (2005). Science, technology and governance in Europe: Challenges of public engagement, STAGE Final Report, vol. 1. http://www.stage-research.net/STAGE/documents/STAGE_Final_Report_final.pdf. (Accessed 23 November 2009)

Hayek, F. (1945). The use of knowledge in society. American Economic Review, 35, 519530.

Hollinger D. A. (1990). Free enterprise and free inquiry: The emergence of laissez-faire communitarianism in the ideology of science in the United States. New Literary History, 21, 897-919. 
Hübner, R. (Ed.). (1967). Aktenstücke und Aufzeichnungen zur Geschichte der Frankfurter Nationalversammlung aus dem Nachlaß von Johann Gustav Droysen (reprint). Osnabrück: Biblio.

Hull, D. L. (1988). Science as a process: An evolutionary account of the social and conceptual development of science. Chicago: University of Chicago Press.

Jasanoff, S. \& Wynne, B. (1998). Science and decision making. In S. Rayner, \& E. Malone (Eds.), Human choice and climate change, vol. 1 (pp. 1-87). Columbus: Battelle Press.

Kant, I. (1991). An answer to the question: 'What is enlightenment?' In H. Reiss (Ed.), Kant's political writings (2nd ed., pp. 54-60), Cambridge: Cambridge University Press.

Kitcher, P. (1990). The division of cognitive labor. The Journal of Philosophy, 87, 5-22.

Kitcher, P. (1993). The advancement of science: Science without legend, objectivity without illusions. New York: Oxford University Press.

Kitcher, P. (2001). Science, truth, and democracy, New York: Oxford University Press.

Longino, H. E. (1990). Science as social knowledge: Values and objectivity in scientific inquiry. Princeton: Princeton University Press.

Longino, H. E. (2002). The fate of knowledge. Princeton: Princeton University Press.

Meiklejohn, A. (1961). The first amendment is an absolute. The Supreme Court Review, 1961, 245-266.

Mill, J. S. (1991). On liberty. In J. Gray (Ed.), On liberty and other essays (pp. 1-128). Oxford: Oxford University Press.

Milton, J. (1918). Areopagitica (R. C. Jebb, Ed.). Cambridge: Cambridge University Press.

Paulsen, F. (1896). Geschichte des gelehrten Unterrichts auf den deutschen Schulen und Universitäten (2nd ed.), vol. 1. Leipzig: Veit.

Popper, K. R. (1972). Objective knowledge: An evolutionary approach. Oxford: Clarendon.

Sarewitz, D. (1996). Frontiers of illusion: Science, technology, and the politics of progress. Philadelphia: Temple University Press.

Sarewitz, D. (2004). How science makes environmental controversies worse. Environmental Science \& Policy, 7, 385-403.

Solomon, M. (2001). Social empiricism. Cambridge, Mass.: MIT Press.

Spinoza, B. (1925). Tractatus theologico-politicus. In C. Gebhardt (Ed.), Opera, vol. 3 (pp. 1-247). Heidelberg: Winter. 
Sunstein, C. (1997). Deliberation, democracy and disagreement. In R. Bontekoe \& M. Stepaniants (Eds.), Justice and democracy: Cross-cultural perspectives (pp. 93-117). Honolulu: University of Hawaii Press.

Union of Concerned Scientists (2008). Scientific freedom and the public good. http://www.ucsusa.org/assets/documents/scientific_integrity/scientific_freedom.pdf. (Accessed 23 November 2009)

Waldron, J. (1993). Social citizenship and the defense of welfare provision. In Liberal rights: Collected papers 1981-1991 (pp. 271-308). Cambridge: Cambridge University Press.

Wolff, C. (1996). Discursus praeliminaris de philosophia in genere / Einleitende Abhandlung über Philosophie im allgemeinen (G. Gawlik \& L. Kreimendahl, Trans. \& Eds.). Stuttgart-Bad Cannstatt: Frommann-Holzboog.

World Congress for Freedom of Scientific Research (2008). Concept paper of the second meeting (Brussels, March 5-7, 2009).

http://www.freedomofresearch.org/files/II_conc_pap_EN_rev[4].pdf. (Accessed 23 November 2009) 